\title{
Occupation and Risk Factors for Type 2 Diabetes: a Study With Health Workers ${ }^{1}$
}

\author{
Vitória de Cássia Félix de Almeida² \\ Maria Lúcia Zanetti ${ }^{3}$ \\ Paulo César de Almeida ${ }^{4}$ \\ Marta Maria Coelho Damasceno ${ }^{5}$
}

We aimed to analyze the interrelationships between occupation and prevalence of risk factors for type 2 diabetes in workers at a hospital in Fortaleza-CE. Cross-sectional study with 299 subjects and form-based, covering socio-demographic concerns and risk factors for Type 2 Diabetes. Results showed that $40.5 \%$ of the sample were nursing workers, $63.9 \%$ were women, $68.6 \%$ were under 35 years of age, $49.5 \%$ had an education level equivalent to high school and $51.9 \%$ had no marriage or stable union. Comparison among the prevalence of risk factors in different occupations was significant $(p<0.05)$ for the following factors: abdominal obesity, waist-hip ratio increased, sedentary lifestyle and HDL-cholesterol $<35$ $\mathrm{mg} / \mathrm{dl}$, and the nursing workers showed higher prevalence levels for these three factors. Hence, within the study context, nursing workers are at an increased risk for developing diabetes in comparison with other health professionals.

Descriptors: Occupational Health; Health Promotion; Diabetes Mellitus; Risk Factors; Nursing.

\footnotetext{
${ }^{1}$ Paper extracted from Doctoral Dissertation "Ocupação e fatores de risco para diabetes mellitus tipo 2: contribuição ao estudo do processo saúde-doença de trabalhadores de saúde", presented to Nursing Graduate Program, Universidade Federal do Ceará, Brazil.

2 Ph.D. in Nursing. Professor, Universidade Regional do Cariri, CE, Brazil. E-mail: vit_vitoriafelix@hotmail.com.

${ }^{3}$ Ph.D. in Nursing. Associate Professor, Escola de Enfermagem de Ribeirão Preto, Universidade de São Paulo, WHO Collaborating Centre for Nursing Research Development, SP, Brazil. E-mail: zanetti@eerp.usp.br.

${ }^{4}$ Ph.D. in Public Health. Professor, Universidade Estadual do Ceará, CE, Brazil. E-mail: pc49almeida@gmail.com.

${ }^{5}$ Ph.D. in Nursing. Professor, Universidade Federal do Ceará, CE, Brazil. E-mail: martadamasceno@terra.com.br.
} 


\section{Ocupação e fatores de risco para diabetes tipo 2: estudo com trabalhadores de enfermagem}

Objetivou-se analisar as inter-relações entre ocupação e prevalência de fatores de risco para diabetes tipo 2. Participaram 299 sujeitos, trabalhadores de um hospital público de Fortaleza, CE. Para a coleta de dados utilizou-se um formulário, contemplando variáveis sociodemográficas e relativas aos fatores de risco para diabetes tipo 2 . Verificou-se que $40,5 \%$ eram trabalhadores de enfermagem, 63,9\% mulheres, 68,6\% tinham menos de 35 anos, 49,5\% tinham escolaridade equivalente ao ensino médio e 51,9\% não possuía vínculo matrimonial, ou união estável. A comparação da prevalência dos fatores de risco nas diferentes ocupações foi significante $(p<0,05)$ para os seguintes fatores: obesidade abdominal, relação cintura/quadril aumentada, sedentarismo, tabagismo e HDL-colesterol $<35 \mathrm{mg} / \mathrm{dl}$, sendo que os trabalhadores de enfermagem apresentaram maior prevalência para 3 desses fatores. Conclui-se que os trabalhadores de enfermagem apresentaram maior risco para desenvolver diabetes mellitus que os demais profissionais de saúde.

Descritores: Saúde do Trabalhador; Promoção da Saúde; Diabetes Mellitus; Fatores de Risco; Enfermagem.

\section{Ocupación y factores de riesgo para diabetes tipo 2: un estudio en trabajadores de enfermería}

Se tuvo por objetivo analizar las interrelaciones entre ocupación y prevalencia de factores de riesgo para Diabetes Tipo 2. Participaron 299 sujetos trabajadores de un hospital público de Fortaleza, estado de Ceará. Para la recolección de datos se utilizó un formulario, contemplando variables sociodemográficas y relativas a los factores de riesgo para Diabetes Tipo 2. Se verificó que 40,5\% eran trabajadores de enfermería, $63,9 \%$ mujeres, 68,6\% tenían menos de 35 años, 49,5\% tenían escolaridad equivalente a la enseñanza media y el $51,9 \%$ no poseía vínculo matrimonial o de unión estable. La comparación de la prevalencia de los factores de riesgo en las diferentes ocupaciones fue significativa $(p<0,05)$ para los siguientes factores: obesidad abdominal, relación cintura/cadera aumentada, sedentarismo, tabaquismo y $\mathrm{HDL}$ colesterol $<35 \mathrm{mg} / \mathrm{dl}$, siendo que los trabajadores de enfermería presentaron mayor prevalencia para 3 de esos factores. Se concluye que los trabajadores de enfermería presentaron mayor riesgo para desarrollar diabetes mellitus que los demás profesionales de salud.

Descriptores: Salud Laboral; Promoción de la Salud; Diabetes Mellitus; Factores de Riesgo; Enfermería.

\section{Introduction}

From an Occupational Health focus, much has been done to clarify the causal relations between exposure in the work environment and cancer, infertility, bonemuscle, neurological and dermatological diseases and hearing impairment ${ }^{(1)}$.

Nevertheless, studies that analyze factors that can predispose workers to the appearance of metabolic disorders, such as type 2 diabetes mellitus 2 (DM2), can be considered incipient. Also, their analysis remains restricted to the identification of risk factors in the study groups, however, without establishing correlations between the work process and the appearance of DM2 ${ }^{(2-8)}$.

Diabetes mellitus is not considered a professional illness, nor is it seen as specific to health workers. The lifestyle these workers adopt, however, can enhance the appearance of the disease. In many cases, workers assume long workdays, multiple jobs, shift work, entailing difficulties to adopt healthy life habits, without mentioning 
that the nature itself of health work confronts its workers with stress and anxiety on a daily base. These have been evidenced as harmful to people's health, making them susceptible to chronic health problems ${ }^{(1,6)}$.

Based on these premises, the goal was to analyze the inter-relations between occupation and prevalence of DM2 risk factors among nursing team members and other hospital professionals.

In this study, the researchers departed from the hypothesis that, in comparison with other hospital workers, nursing team members present higher prevalence rates of risk factors for the development of type 2 diabetes mellitus.

The hypothesis is based on the finding that nursing work differs from other professional activities, even in the health sector, as a result of aspects related to the work object itself, the way the work is developed and the physical, mental and psychic demands nursing team members experience when developing their actions. These can turn nursing workers unable in terms of selfcare practice, consequently predisposing them to the establishment of critical risk factors for the development of chronic illnesses ${ }^{(4,9)}$.

\section{Method}

A cross-sectional research was carried out at a public hospital in Fortaleza-CE between March 2003 and March 2007.

The hospital staff comprises 433 members, of whom 299 health workers were investigated, considered here as "anyone directly or indirectly inserted in health service delivery, inside health establishments or in health activities, who may possess specific education or not to perform functions related to the sector"(10).

To select the participants, the research was widely disseminated at the institution, involving: sending an invitation with the paycheck, visiting all hospital sectors, hanging up posters and informing about the research.

The following were excluded from the study: subjects previously diagnosed with diabetes, employees on holidays or leave of absence and anyone who refused to participate in the research.

For the sake of this study, workers were categorized as follows: Nursing workers: group including nurses, nursing technicians and auxiliaries at the institution; Physicians; Other higher-education professionals: group including health professionals with higher-education degrees different from the previous groups, such as physiotherapists, pharmacists, nutritionists, among others; Administrative workers: group involving the institution's administrative staff, such as managers, secretaries, administrative technicians, accounting assistants, among others and General service workers: group comprising workers not grouped in the previous categories, including general service aids, maintenance aids, guards, drivers, porters, doormen, among others.

Through the application of a form, anthropometric assessment, blood pressure measurement and blood sample collection, the subjects' socio-demographic characteristics were assessed, as well as the following risk factors for DM2(11-14): age >40 years; overweight (identified through Body Mass Index - BMI analysis); abdominal obesity (estimated through abdominal circumference - AC); increased waist-hip ratio (WHR); sedentariness; smoking; stress; systemic arterial hypertension $(\mathrm{SAH}) ; \mathrm{HDL}<35 \mathrm{mg} / \mathrm{dl}$; and triglycerides $\geq 200 \mathrm{mg} / \mathrm{dl}$.

To verify participants' body weight, portable scales with a $0.1 \mathrm{~kg}$ precision level were used. The subject was placed standing, barefoot, on top of and at the center of the platform, straight and looking towards a point ahead. Height was measured with a metric centimeter tape, fixed against the wall and with the help of a wooden indicator, placed at $90^{\circ}$ from the scale. Participants stood up straight, with their head parallel to the floor, arms stretched along the body, barefoot and with their feet joined, attempting to put the back of the heel, pelvic waist, scapular waist and occipital region in contact with the measurement instrument.

The waist (WC), abdominal (AC) and hip circumference $(\mathrm{HC})$ were measured in a private place, with the participant standing in the orthostatic position, relaxed abdomen, arms slightly distanced from the body and feet joined. Using an inextensible metric tape, the waist circumference was measured at the middle point between the final rib and the iliac crest, the hip was measured at the level of the great trochanter of the femur, at the largest gluteal circumference point, while the abdomen was measured at the height of the umbilical $\operatorname{scar}^{(13,15)}$. Very high AC measures were considered as abdominal obesity, such as $A C \geq 102 \mathrm{~cm}$ for men and $88 \geq$ $\mathrm{cm}$ for women ${ }^{(13)}$.

The Body Mass Index was calculated by dividing body weight in kilograms by the squared height in meters $\left(\mathrm{kg} / \mathrm{m}^{2}\right)$ and the Waist-Hip Ratio by dividing the waist circumference by the hip circumference. People with $\mathrm{BMI} \geq 25 \mathrm{Kg} / \mathrm{m}^{2}$ were considered overweight. For increased WHR, the cut-off points were 0.95 for men and 0.80 for women ${ }^{(14-16)}$. 
Blood pressure was measured with aneroid sphygmomanometers, calibrated and checked by INMETRO (National Institute of Metrology, Standardization and Industrial Quality) and with adequate cuff sizes for the interviewees' arm circumference ${ }^{(16)}$. For measurement purposes, some aspects were strictly observed, such as 5-10 minutes of rest, empty bladder, no consumption of alcoholic beverages, coffee or tobacco within 30 minutes before the blood pressure measurement. Orientations regarding the interviewees' positioning were also observed, who should be seated, with supported back and legs uncrossed. The measurement device should be placed between 2 and $3 \mathrm{~cm}$ above the cavity. The manometer was placed on the bare arm, supported at the level of the precordium and with the hand palm turned upwards ${ }^{(11)}$. Subjects were considered hypertensive if they declared themselves so, took anti-hypertensive medication or showed systolic blood pressure levels (SAP) $\geq 140 \mathrm{mmHg}$ and diastolic levels (DAP) $\geq 90 \mathrm{mmHg}^{(17)}$.

As for sedentariness, this was considered as the absence of physical activity, i.e. regular physical exercise practiced at least twice per week with a minimum duration of 30 minutes. Smoking, on the other hand, was characterized as daily consumption of any number of cigarettes or similar products. Regarding stress, selfreference about the presence or not of this risk factor was taken into account.

To assess HDL-cholesterol and triglycerides, blood samples were also collected at the hospital, involving a trained laboratory aid, through venipuncture with a Vacutainer. Labtest ${ }^{\circledR}$ kits were used for biochemical analysis, according to the manufacturer's orientations. Out of 299 research participants, 147 attended. All subjects received previous orientations about the need for 12-hour fasting.

It is highlighted that, although the number of participants in the second phase dropped to 147, this sample is still considered representative of the study population, as the maximum error permitted remained below the $5 \%$ recommended in literature for sample size calculations $^{(18)}$.

Approval for the research protocol was obtained from the Institutional Review Board at Ceará Federal University (Protocol No 241/04). All subjects signed a Free and Informed Consent Term.

Statistical Package for the Social Sciences (SPSS) software, version 13.0, was used for statistical data treatment. For data analysis, the epidemiological measure Prevalence Ratio (PR) was calculated, confidence intervals were verified and proportion tests were carried out for the PRs. For all tests, significance was set at $5 \%$.

\section{Results}

Table 1 shows the sample's socio-demographic characteristics, mostly comprising female subjects (63.9\%) younger than 35 years (68.6\%). As for education, secondary level predominated (49.5\%). Most subjects were nursing staff members, with 22 nurses, 7 technicians and 92 auxiliaries, representing $40.5 \%$ of all subjects.

Table 1 - Distribution of workers according to sociodemographic variables - Fortaleza-CE, 2007

\begin{tabular}{|c|c|c|}
\hline Variable & $\mathbf{N}$ & $\%$ \\
\hline \multicolumn{3}{|l|}{ 1. Gender } \\
\hline Female & 191 & 63.9 \\
\hline Male & 108 & 36.1 \\
\hline \multicolumn{3}{|l|}{ 2. Marital Status } \\
\hline Single & 135 & 45.2 \\
\hline Married & 129 & 43.1 \\
\hline Stable Union & 15 & 5.0 \\
\hline Divorced & 20 & 6.7 \\
\hline \multicolumn{3}{|l|}{ 3. Education level } \\
\hline Primary Education & 41 & 13.7 \\
\hline Secondary Education & 148 & 49.5 \\
\hline Higher Education & 110 & 36.8 \\
\hline \multicolumn{3}{|l|}{ 4. Occupation } \\
\hline Nursing worker & 121 & 40.5 \\
\hline Physician & 29 & 9.7 \\
\hline Other higher education professionals & 11 & 3.7 \\
\hline General service workers & 97 & 32.4 \\
\hline Administrative workers & 41 & 13.7 \\
\hline \multicolumn{3}{|l|}{ 6. Age range (years) } \\
\hline $19-25$ & 50 & 16.7 \\
\hline $26-30$ & 69 & 23.1 \\
\hline $31-35$ & 86 & 28.8 \\
\hline $36-40$ & 50 & 16.7 \\
\hline $41-55$ & 44 & 14.7 \\
\hline
\end{tabular}

In view of the research goal, that is, to verify whether prevalence levels of risk factors for type 2 diabetes mellitus would be higher among nursing workers, all research variables, which were considered as risk factors for the disease according to the analyzed literature, were submitted to Prevalence Ratio (PR) analysis, comparing the ratios for the nursing workers' risk factors with those of other occupational groups (Tables 2-4). 
Table 2 - Distribution of research participants according to Prevalence Ratio of risk factors related to anthropometric variables - Fortaleza-CE, 2007

\begin{tabular}{|c|c|c|c|c|c|c|c|}
\hline \multirow{2}{*}{ Risk factor } & \multicolumn{2}{|c|}{ Present } & \multicolumn{2}{|c|}{ Absent } & \multirow{2}{*}{ RP } & \multirow{2}{*}{ IC95\% } & \multirow{2}{*}{$\mathbf{p}$} \\
\hline & $\mathbf{N}$ & $\%$ & $\mathbf{N}$ & $\%$ & & & \\
\hline \multicolumn{8}{|l|}{ Age $>40$ years } \\
\hline Nursing workers & 21 & 17.4 & 100 & 82.6 & & & \\
\hline Physicians & 2 & 6.9 & 27 & 93.1 & 2.517 & $0.625-10.130$ & 0.262 \\
\hline Higher education professionals & 1 & 9.1 & 10 & 90.9 & 1.909 & $0.283-12.876$ & 0.776 \\
\hline General services & 15 & 15.5 & 82 & 84.5 & 1.122 & $0.612-2.058$ & 0.848 \\
\hline Administrative services & 5 & 12.2 & 36 & 87.8 & 1.423 & $0.574-3.531$ & 0.591 \\
\hline \multicolumn{8}{|l|}{ Overweight } \\
\hline Nursing workers & 58 & 47.9 & 63 & 52.1 & & & \\
\hline Physicians & 11 & 37.9 & 18 & 62.1 & 1.264 & $0.766-2.086$ & 0.445 \\
\hline Higher education professionals & 5 & 45.5 & 6 & 54.6 & 1.055 & $0.538-2.068$ & 0.871 \\
\hline General services & 47 & 48.5 & 50 & 51.5 & 0.989 & $0.750-1.305$ & 0.962 \\
\hline Administrative services & 20 & 48.8 & 21 & 51.2 & 0.983 & $0.682-1.415$ & 0.935 \\
\hline \multicolumn{8}{|l|}{ Abdominal obesity } \\
\hline Nursing workers & 49 & 41.2 & 70 & 58.8 & & & \\
\hline Physicians & 5 & 17.2 & 24 & 82.8 & 2.388 & $1.046-5.454$ & 0.028 \\
\hline Higher education professionals & 2 & 20.0 & 8 & 80.0 & 2.059 & $0.585-7.244$ & 0.327 \\
\hline General services & 25 & 26.3 & 70 & 73.7 & 1.565 & $1.050-2.332$ & 0.032 \\
\hline Administrative services & 11 & 26.8 & 30 & 73.2 & 1.535 & $0.886-2.658$ & 0.145 \\
\hline \multicolumn{8}{|l|}{ Increased WHR } \\
\hline Nursing workers & 39 & 32.8 & 80 & 67.2 & & & \\
\hline Physicians & 4 & 13.8 & 25 & 86.2 & 2.376 & $0.923-6.117$ & 0.073 \\
\hline Higher education professionals & 1 & 10.0 & 9 & 90.0 & 3.277 & $0.502-21.416$ & 0.221 \\
\hline General services & 21 & 22.1 & 74 & 77.9 & 1.483 & $0.939-2.341$ & 0.115 \\
\hline Administrative services & 6 & 14.6 & 35 & 85.4 & 2.239 & $1.024-4.899$ & 0.042 \\
\hline
\end{tabular}

Table 3 - Distribution of research participants according to Prevalence Ratio of risk factors related to behavioral variables and health history - Fortaleza-CE, 2007

\begin{tabular}{|c|c|c|c|c|c|c|c|}
\hline \multirow{2}{*}{ Risk factor } & \multicolumn{2}{|c|}{ Present } & \multicolumn{2}{|c|}{ Absent } & \multirow{2}{*}{ PR } & \multirow{2}{*}{$\mathrm{Cl} 195 \%$} & \multirow{2}{*}{$\mathbf{p}$} \\
\hline & $\mathbf{N}$ & $\%$ & $\mathbf{N}$ & $\%$ & & & \\
\hline \multicolumn{8}{|l|}{ Sedentariness } \\
\hline Nursing workers & 103 & 85.1 & 18 & 14.9 & & & \\
\hline Physicians & 15 & 51.7 & 14 & 48.3 & 1.646 & $1.149-2.358$ & 0.0001 \\
\hline Higher education professionals & 9 & 81.8 & 2 & 18.2 & 1.040 & $0.780-1.388$ & 0.883 \\
\hline General services & 60 & 61.9 & 37 & 38.1 & 1.376 & $1.157-1.636$ & 0.0001 \\
\hline Administrative services & 25 & 61.0 & 16 & 39.0 & 1.396 & $1.081-1.803$ & 0.002 \\
\hline \multicolumn{8}{|l|}{ Smoking } \\
\hline Nursing workers & 5 & 4.1 & 116 & 95.6 & & & \\
\hline Physicians & - & - & 29 & 100.0 & - & - & - \\
\hline Higher education professionals & - & - & 11 & 100.0 & - & - & - \\
\hline General services & 19 & 19.6 & 78 & 80.4 & 0.211 & $0.082-0.545$ & 0.0001 \\
\hline Administrative services & 1 & 2.4 & 40 & 97.6 & 1.694 & $0.204-11.081$ & 0.984 \\
\hline \multicolumn{8}{|l|}{ Stress } \\
\hline Nursing workers & 42 & 35.0 & 78 & 65.0 & & & \\
\hline Physicians & 13 & 44.8 & 16 & 55.2 & 0.781 & $0.487-1.251$ & 0.443 \\
\hline Higher education professionals & 5 & 45.5 & 6 & 54.5 & 0.770 & $0.386-1.583$ & 0.714 \\
\hline General services & 31 & 32.3 & 65 & 67.7 & 1.084 & $0.742-1.583$ & 0.786 \\
\hline Administrative services & 15 & 36.6 & 26 & 63.4 & 0.957 & $0.597-1.532$ & 0.997 \\
\hline \multicolumn{8}{|l|}{ Hypertension } \\
\hline Nursing workers & 21 & 17.4 & 100 & 82.6 & & & \\
\hline Physicians & 3 & 10.3 & 26 & 89.7 & 1.678 & $0.537-5.245$ & 0.513 \\
\hline Higher education professionals & 2 & 18.2 & 9 & 81.8 & 0.955 & $0.257-3.547$ & 0.728 \\
\hline General services & 22 & 22.7 & 75 & 77.3 & 0.765 & $0.448-1.307$ & 0.421 \\
\hline Administrative services & 13 & 31.7 & 28 & 68.3 & 0.547 & $0.302-0.992$ & 0.085 \\
\hline
\end{tabular}


Based on the information presented in Tables 2 and 3 , statistically significant differences $(p<0.05)$ are found in prevalence ratios for the following risk factors: abdominal obesity, increased WHR, sedentariness and smoking.

Also, the prevalence of abdominal obesity was higher among nursing workers than in all other study groups. Only comparisons with physicians and administrative workers were significant though, evidencing that prevalence levels for the above risk factor are almost 2.4 times higher for the nursing group than for physicians $\left(\mathrm{CI}_{95 \%} 1.046-5.454 ; \mathrm{p}=0.028\right)$ and almost 1.6 times higher than for general service workers $\left(\mathrm{CI}_{95 \%} 1.050-\right.$ 2.332; $\mathrm{p}=0.032$ ).

Another risk factor that showed statistically significant difference in prevalence ratios among workers was increased WHR. Based on Table 2, like with the abdominal obesity factor, nursing workers also presented higher prevalence levels in comparison with other professional groups in this study. The PR was only statistically significant, however, when comparing nursing workers and administrative staff, i.e. 2.2 higher for the former than for the latter $\left(\mathrm{CI}_{95 \%} 1.024-4.899\right.$; $\mathrm{p}=0.042$ ).

Regarding sedentariness, prevalence was higher among nursing workers. In comparison with physicians, these workers were almost 1.7 times more sedentary $\left(\mathrm{CI}_{95 \%} 1.149-2.358 ; \mathrm{p}<0.0001\right)$. They were also about 1.4 times more sedentary than general service staff $\left(\mathrm{CI}_{95 \%} 1.157-1.636 ; \mathrm{p}<0.0001\right)$ and administrative staff $\left(\mathrm{CI}_{95 \%} 1.081-1.803 ; \mathrm{p}=0.002\right)$.

As for smoking, being a nursing worker represented a smaller chance of displaying this risk factor in comparison with general service workers (PR 0.211; $\mathrm{CI}_{95 \%} 0.082-0.545 ; \mathrm{p}<0.0001$ ).

Table 4 shows the comparisons among prevalence ratios of risk factors for DM2 associated with the lipid profile. Only comparisons for HDL-cholesterol showed to be significant, demonstrating that, in comparison with administrative service workers, nursing workers prevalence ratios were lower for this risk factor $(P R=$ $0.375 ; \mathrm{CI}_{95 \%} 0.161-0.872 ; \mathrm{p}=0.037$ ).

Table 4 - Distribution of research participants according to occupation and risk factors associated with lipid alterations. Fortaleza-CE, 2007

\begin{tabular}{|c|c|c|c|c|c|c|c|}
\hline \multirow{2}{*}{ Risk factor } & \multicolumn{2}{|c|}{ Present } & \multicolumn{2}{|c|}{ Absent } & \multirow{2}{*}{ PR } & \multirow{2}{*}{$\mathrm{Cl95 \%}$} & \multirow{2}{*}{$\mathbf{p}$} \\
\hline & $\mathbf{N}$ & $\%$ & $\mathbf{N}$ & $\%$ & & & \\
\hline \multicolumn{8}{|l|}{$\mathrm{HDL}<35 \mathrm{mg} / \mathrm{dl}$} \\
\hline Nursing workers & 7 & 12.5 & 49 & 87.5 & & & \\
\hline Physicians & 2 & 33.3 & 4 & 66.7 & 0.375 & $0.099-1.414$ & $\left({ }^{*}\right)$ \\
\hline Higher education professionals & 2 & 40.0 & 3 & 60.0 & 0.313 & $0.087-1.121$ & $\left({ }^{*}\right)$ \\
\hline General services & 9 & 19.1 & 38 & 80.9 & 0.653 & $0.263-1.619$ & 0.517 \\
\hline Administrative services & 11 & 33.3 & 22 & 66.7 & 0.375 & $0.161-0.872$ & 0.037 \\
\hline \multicolumn{8}{|l|}{ Altered triglycerides } \\
\hline Nursing workers & 6 & 10.7 & 50 & 89.3 & & & \\
\hline Physicians & - & - & 6 & 100.0 & - & - & - \\
\hline Higher education professionals & - & - & 5 & 100.0 & - & - & - \\
\hline General services & 6 & 12.8 & 41 & 87.2 & 0.839 & $0.290-2.430$ & 0.982 \\
\hline Administrative services & 5 & 15.2 & 28 & 84.8 & 0.707 & $0.234-2.137$ & 0.772 \\
\hline
\end{tabular}

(*) Test not performed, as $\mathrm{N}$ was very small.

\section{Discussion}

One of the first aspects to be commented on regarding the findings relates to the mostly female participants. This fact underlines the predominance of women in the hospital workforce.

From the perspective of DM2 risk, no significant gender differences are observed, considering that other studies indicate similar prevalence ratios in men and women ${ }^{(19)}$.
In fact, characterization according to gender only gains relevance when associated with other factors like BMI and WHR, in which a strong correlation has been reported between alterations in these variables and the female gender ${ }^{(20)}$.

Regarding education, the research subjects showed a good education level, considering that $86.3 \%$ had a secondary or higher education degree. This can be an 
important group characteristic, disclosing potential to put in practice education strategies with a view to health promotion.

Regarding the age range, the fact stands out that most of the sample consisted of young workers. Hence, they had not reached the critical age for the appearance of DM2.

Age constitutes a factor of independent predictive value for chronic illnesses, and is also used as a parameter to classify a person's risk for the development of nondiagnosed hyperglycemia(21).

As for the analyzed risk factors, higher prevalence ratios were identified among nursing workers, with statistical significance, for increased WHR, abdominal obesity and sedentariness.

Regarding the waist-hip ratio, this measure is used to characterize body fat distribution types. The proportion indicates the quantity of fat in the upper part of the body in relation to the lower part, with high WHR determining an android obesity pattern - implying high risk for diseases like type 2 diabetes mellitus. Low WHR, in turn, reveals a gynoid obesity pattern, with a greater fat proportion located in the lower body part.

The central (android) obesity pattern is associated with increased blood glucose and triglyceride levels, as well as with a greater possibility of developing diabetes and cardiovascular disease ${ }^{(16)}$.

Regarding abdominal obesity, an important risk factor for diabetes, the fact stands out that the nursing group presented higher prevalence ratios for this parameter than all other groups, although nursing workers did not obtain the highest statistically significant prevalence of overweight (high BMI). This underlines the importance of correlating anthropometric variables with a view to greater knowledge on individual risks for chronic illnesses in general and specifically for DM2, considering that the BMI is useful to identify overweight, but does not manage to explain different body fat distributions ${ }^{(16,20)}$.

Another significantly more prevalent risk factor among nursing workers was sedentariness. Inactivity or a low quantity of physical activity can be a workassociated factor when considering that some professions or occupations, due to its own characteristics, limit professionals' physical activity. At other times, when workers perform a certain activity that demands frequent dislocations from their work station - and this seems to be the case of nursing work - this generates a false feeling that the body is active. For a physical activity to have protective health effects, however, it should take place continuously, regularly and at adequate intensity levels.

The sedentary condition of the study subjects becomes even more important when considering that, besides constituting a risk factor for DM2, sedentariness surpasses the other risk factors that were presented, such as overweight and abdominal obesity, enhancing their effects and, thus, considerably increasing the chances that these subjects will become diabetics.

As for smoking, literature has demonstrated that smoking is negatively associated with the qualification of professional occupations in terms of specialization level(4). This fact was also evidenced in this research, which found that being a nursing worker resulted in lesser chances of being a smoker in comparison with general service workers $(p<0.05)$.

Regarding the analysis of HDL as a risk factor for DM2, being a nursing worker resulted in a lesser chance of presenting low HDL-Cholesterol levels in comparison with administrative workers. Considering that serum HDL levels are closely related with physical exercise ${ }^{(14)}$, the fact that nursing workers - despite being the most sedentary group - showed lower prevalence ratios for this risk factor may be related with the sample group's food habits. This fact can be a target of future research.

\section{Conclusion}

In this research, the intent was to analyze the inter-relations between occupation and prevalence of risk factors for type 2 Diabetes Mellitus among nursing workers and other health workers, based on the hypothesis that nursing team members, in comparison with other hospital workers active in other occupations, present higher prevalence levels of risk factors for the development of type 2 DM.

Based on the Prevalence Ratio analysis, applied to all DM2 risk factors under analysis, the following showed to be statistically significant: abdominal obesity, altered WHR, sedentariness, smoking and HDLcholesterol<35mg/dl.

Among statistically significant risk factors, the most prevalence among nursing workers were: abdominal obesity, altered WHR and sedentariness.

Thus, it is concluded that, in the study context, nursing workers are at greater risk of developing diabetes than other health professionals.

It is clear that, from a biological viewpoint, being a health or nursing worker does not determine whether a person will be a diabetes patient or not, in view of 
current epidemiological knowledge. On the other hand, work can indirectly influence this process, interfering in socio-demographic and psychosocial variables and thus representing an extremely important analytic focus, mainly in case of a disease like DM2, which is a target of interest for primary prevention. The later is essentially based on analysis of and intervention in a subject's total risk profile for a health problem, including not only biological aspects.

The researchers hope that, to a certain extent, this study can contribute to the debate about risk factors for type 2 diabetes mellitus in nursing workers and, to a greater extent, to the maintenance of occupational health.

\section{Acknowledgements}

Sincerely acknowledgements to Ana Roberta Vilarouca da Silva, Suyanne Freire de Macedo, Hérica Cristina Alves de Vasconcelos, Niciane Bandeira Pessoa Marinho for data collection.

\section{References}

1. Mendes $\mathrm{R}$, organizador. Patologia do trabalho. 2. ed. São Paulo: Atheneu; 2005. 2910 p.

2. Martinez MC, Latorre MRDO. Fatores de risco para hipertensão arterial e diabete melito em trabalhadores de empresa metalúrgica e siderúrgica. Arq Bras Cardiol. 2006; 87(4):471-9.

3. Damasceno MMC, Almeida PC, Almeida VCF, Macêdo SF, Silva ARV. Perfil dos níveis pressóricos e glicêmicos de funcionários de instituições públicas hospitalares de Fortaleza-Ceará. Esc Anna Nery Rev Enferm. 2006; $10(2): 228-34$

4. Vilarinho RMF. Os fatores de risco para o diabetes mellitus e as ações de autocuidado entre os trabalhadores de enfermagem [dissertação de mestrado]. Rio de Janeiro (RJ): Escola de Enfermagem Anna Nery/UFRJ; 2004. $153 \mathrm{p}$

5. Shi FY, Du Q, Liu YY, Gao ZX, Qin LP, Song Y, Jia FY. [An epidemiologic study of diabetes mellitus in employees of Baotou Iron and Steel Company]. Zhonghua Yu Fang Yi Xue Za Zhi [Chin J Prev Med.] 2003; 37(5):361-4.

6. Ortiz MCA, Zanetti ML. Survey on risk factors for type-2 diabetes mellitus in an undergraduation school. Rev. Latino-Am. Enfermagem. 2001; 9(3):58-63. Inglês, Português, Espanhol.
7. Pinto JESS, Merino RGP, Fonseca $M L$, Santos RB, Oliveira JEP, Sant'anna NMM, et al. Avaliação da glicemia em funcionários da UFRJ. Arq Bras Endocrinol Metab. 2001; 45(5): Supl.1:567

8. Sousa MC, Damasceno MMC, Loureiro MFF, Sales ZN, Marques RLL, Almeida PC. Estimativa do potencial para desenvolver diabetes mellitus nos servidores do Hospital Universitário Walter Cantídio da Universidade Federal do Ceará. Rev RENE. 2001; 2(2):25-30.

9. Elias MA, Navarro, VL. A relação entre o trabalho, a saúde e as condições de vida: negatividade e positividade no trabalho das profissionais de enfermagem de um hospital-escola. Rev. Latino-Am. Enfermagem. 2006; 14(4):517-25.

10. Risco Biológico. Risco biológico e profissionais de saúde. [acesso 20 jan 2004]. Disponível em: http:// www.riscobiológico.org/riscos/riscos.htm.

11. Ministério da Saúde (BR). Plano de reorganização da atenção à hipertensão arterial e ao diabetes mellitus: manual de hipertensão arterial e diabetes mellitus. Brasília (DF): Ministério da Saúde; 2002. 102 p.

12. American Diabetes Association. Diagnosis and classification of diabetes mellitus. Diabetes Care. 2004; 27 Suppl 1: S5-10.

13. Consenso Latino Americano de Obesidade. Arq Bras Endocrinol Metab. 1999; 43(1):21-67.

14. III Diretrizes Brasileiras Sobre Dislipidemias $e$ Diretriz de Prevenção da Aterosclerose do Departamento de Aterosclerose da Sociedade Brasileira de Cardiologia. Arq Bras Cardiol. 2001; 77 Supl 3:1-48. [acesso $15 \mathrm{fev}$ 2007]. Disponível em: http://publicacoes.cardiol.br/ consenso/2001/77Supl-III/Dislipidemia.pdf

15. Fernandes J Filho. A prática da avaliação física: testes, medidas e avaliação física em escolares, atletas e academias de ginástica. 2.ed. rev. atual. Rio de Janeiro: Shape; 2003. 268 p.

16. Navarro AM, Stedille MS, Unamuno MRDL, Marchini JS. Distribuição da gordura corporal em pacientes com e sem doenças crônicas: uso da relação cintura-quadril e do índice de gordura do braço. Rev Nutr. 2001; 14(1):37-41. 17. Sociedade Brasileira de Hipertensão - $\mathrm{SBH}_{\text {, }}$ Sociedade Brasileira de Cardiologia - SBC e Sociedade Brasileira de Nefrologia - SBN. IV Diretrizes Brasileiras de Hipertensão Arterial. Arq Bras Cardiol. 2004;82Supl 4:7-14

18. Gil AC. Métodos e técnicas de pesquisa social. 5.ed. São Paulo:Atlas; 2006. 207p. 
19. Gale EA, Gillespie KM. Diabetes and gender. Diabetologia. 2001;44(1):3-15.

20. Afonso FM, Sichieri R. Associação do índice de massa corporal e da relação cintura/quadril com hospitalizações em adultos no Município do Rio de Janeiro, RJ. Rev Bras Epidemiol. 2002; 5(2):153-63.

21. Park PJ, Griffin SJ, Sargeant L, Wareham NJ. The performance of a risk score in predicting undiagnosed hyperglycemia. Diabetes Care. 2002; 25(6):984-8. 